\title{
Między porządkami - o transgeniczność wyobraźni politologicznej
}

\section{Between Order: About Transgenicness of Politological Imagination}

\begin{abstract}
The paper presents the conception of "politological imagination" as a specifical scientific tool allowing to search political world in a more effective manner. Indicating possible errors in the thinking of political categories (it is mistaken to confuse the term "imagination" and "fantasy" or implement Mills's sociological imagination theory), the author emphasisies ambiguous nature of that presupposition. Politological imagination is related to different dimensions of reality: real order of reality and cognitive order, but the main focus will remain on cognitive aspect, not creation of political world. It has a quasi-heuristic dimension, but it does not implicate a specific research base. It is dependent on the scope of imagination (it includes historicism, dialectics, anthropological and critical factors) and its strength (it is related to the researcher's interference in the socio-political world).
\end{abstract}

Keywords: political imagination, sociological imagination, knowledge in science about politics

\section{Wprowadzenie}

Analiza obecności rozmaitych odmian wyobraźni w naukach społecznych i humanistycznych skłania do twierdzenia, że pojęcie to występuje w wewnętrznym krwioobiegu określonej dyscypliny w momentach szczególnego przesilenia - kiedy pogłębia się świadomość rozdźwięku pomiędzy stosowanymi coraz bardziej wyrafinowanymi narzędziami badawczymi a osiąganymi rezultatami, które finezji owej nie odzwierciedlają, a co ważniejsze, nie zaspokajają elementarnej potrzeby wyjaśnienia/zrozumienia świata społecznego. Pojawiający się wówczas wśród badaczy sceptycyzm co do możliwości poznania istotnej prawdy o rzeczywistości stwarza sprzyjające warunki do poszukiwania antidotum. 
Jakkolwiek stan poznawczego rozczarowania jest wspólny dla przedstawicieli nauk społecznych i humanistycznych (choć przeżywany w różnym czasie), sposób pojmowania wyobraźni na gruncie poszczególnych dyscyplin bywa już bardzo różny, co stanowi wypadkową zdiagnozowanych deficytów i oczekiwań badawczych. Stąd też, w kanonicznym wariancie Millsowskiej „wyobraźni socjologicznej”, pojmowanej jako „najbardziej pożyteczna z form samoświadomości” (Mills, 2007, s. 55), nacisk położony jest na walor praktyczny tej umiejętności - pozwalający nie tylko na określenie własnego miejsca w otaczającej rzeczywistości, ale również na udział w jej naprawie. Zamysł amerykańskiego klasyka dostrzeżemy wyraźnie w - znacznie późniejszej - koncepcji „wyobraźni ekonomicznej" (Koźmiński, 2016) ${ }^{1}$, pomyślanej również jako świadomościowe narzędzie kształtowania gospodarczej i finansowej pozycji jednostki. Z kolei „wyobraźnia etnograficzna”, stworzona i utrwalona w antropologii kulturowej za sprawą Paula Willisa (2005; zob. też: Mencwel, 2006, s. 9-24), odnosi się nie tyle do praktyk społecznych, ile do praktyki poznawczej, i jako integralna część wypracowanego programu badawczego służy do ekstrakcji i analizy doświadczenia indywidualnego. Również po stronie kompetencji poznawczych sytuowana jest wyobraźnia w historii, gdzie inspiracje teorią krytyczną prowadzą w ostateczności także do dowartościowania jednostkowych tożsamości i doświadczeń, choć droga do tego prowadząca jest inna (via psychoanaliza [LaCapra, 2009; White, 2014]).

W przestawionym wyżej kontekście stanowisko politologii, która nie wypracowała do tej pory własnej koncepcji wyobraźni politologicznej, wydawać się może osobliwe, staje się ono jednak bardziej zrozumiałe, gdy uwzględnimy burzliwe losy kształtowania samej dyscypliny. Nieobecność analogicznej kategorii $w$ nauce o polityce nie wynika bowiem $z$ bezkrytycznego stosunku do wypracowywanych rezultatów badawczych, lecz z wyraźnego opóźnienia, z jakim politologia reaguje na zmiany (zachodzące zarówno w wymiarze społeczno-politycznym, jak i naukowym). Tym zatem, co różni naukę o polityce od pozostałych nauk społecznych (z którymi dzieli ona podobne rozterki i dylematy, jakie pojawiają się we współczesnej nauce), jest fakt, że dyscyplina ta stosunkowo niedawno zerwała $\mathrm{z}$ monopolem pojmowanego dość konserwatywnie empiryczno-analitycznego modelu wiedzy. Przyznając sobie prawo do poszukiwania prawdy o świecie poza dominującym kanonem uprawiania nauki, stworzyła ona dogodną przestrzeń do operowania wyobraźnią - wyobraźnią szytą na miarę potrzeb i oczekiwań politologii.

Podkreślić jednak należy, że sposób posługiwania się kategorią wyobraźni ekonomicznej nadal nie jest jednorodny, a „świadomościową” koncepcję Andrzeja K. Koźmińskiego poprzedzały propozycje łączące to pojęcie ze zdolnością do spekulacji giełdowych (zob. Hill, 2015). 


\section{Czym nie jest wyobraźnia politologiczna}

Posługiwanie się kategorią wyobraźni w kontekście naukowym naraża badacza na szereg zagrożeń bądź nieporozumień dostrzeganych już od czasów Kanta. „Uznawał on wyobraźnię za zdolność, która mając jedynie charakter preracjonalny bądź pararacjonalny, stanowi problem zarówno dla czystego, jak i praktycznego rozumu. Ma ona, jego zdaniem, skłonność do odbiegania od swojego właściwego zadania polegającego na dostarczaniu rozumowi obrazów oraz na degeneracji do poziomu fantazji, wymyślności, figlarności” (White, 2014, s. 81). Świadomość opisanego ryzyka sprawia, że analizę wyobraźni politologicznej jako kategorii odnoszącej się do szczególnej predyspozycji badawczej rozpocząć należy od krytycznego odniesienia się do dwóch tropów eksplanacyjnych, jakie nasuwają się już na wstępnym etapie rozważań.

Trop pierwszy, wypływający z myślenia potocznego, sugeruje związek interesującej nas kategorii z szeroko rozumianym pojęciem fantazji, pojmowanej jako „umiejętność wyobrażenia sobie czegoś, co w realnym świecie jest mało prawdopodobne lub nierealne" (Mały stownik..., 1969, s. 171). Taka perspektywa postrzegania wyobraźni politologicznej nie wydaje się jednak właściwa, ponieważ prowadzi do nieuzasadnionego utożsamiania wyobraźni z przejawami innego osobliwego zjawiska, które określić moglibyśmy mianem fantazji politologa. Abstrahując od szczegółowego opisu etiologii i skutków tejże odmiany fantazji ${ }^{2}$, zasadnicza różnica pomiędzy tymi kategoriami sprowadza się do stosunku do nierealnego. Dwa elementy konstytuujące fantazję per se, to znaczy odrealnienie oraz magiczność, w wypadku wyobraźni politologicznej stanowią groźne pułapki ${ }^{3}$, czyhające na badaczy zjawisk społeczno-politycznych. Tym bowiem, co przesądza o specyfice analizowanej predyspozycji badawczej, jest jej trwały, organiczny związek ze światem społecznym. Siła tego powiązania wynika z faktu, że ma ono różnorodny i wieloaspektowy charakter: zarówno podmiotowy (badacz dysponujący wyobraźnią jest jednocześnie - bardziej lub mniej aktywną

Przejawem tego, co określiliśmy mianem „fantazji politologa”, jest postawa opisywana przez Magdalenę Ozimek jako realizacja „predykcji w «zwyrodniałej formie», za pomocą której zaspokajane jest medialne zapotrzebowanie na dyskusje na granicy spekulanctwa. Sytuacja ta rodzi wręcz możliwość formułowania nowych typologii politologów-wróżbitów czy politologów celebrytów" (Ozimek, 2016, s. 51; por. też: Karwat, 2012).

3 Prawdopodobnie ofiarą tych pułapek okazał się chiński taksonomista, który zamieścił w starożytnej encyklopedii następujący podział zwierząt: „1) stanowiące własność cesarza, 2)zabalsamowane, 3) oswojone, 4) prosięta, 5) syreny, 6) bajeczne, 7) dzikie psy, 8) włączone do tej klasyfikacji, 9) zachowujące się jak szalone, 10) nieprzeliczalne, 11) narysowane cieniutkim pędzelkiem $\mathrm{z}$ wielbłądziej sierści, 12) i im podobne, 13) te, które stłukły wazon, 14) te, które z daleka wyglądają jak muchy” (de Pracontal, 1983, cyt. za: Nęcka [i in.], 2005, s. 57). 
- częścią analizowanej rzeczywistości i jako taki wpływa na jej kształt $\left.{ }^{4}\right)$, przedmiotowy (składowe świata politycznego są budulcem treściowym dla wyobraźni), jak i relacyjny (wyobraźnia „mediuje” pomiędzy wymiarem poznawczym a materialnym świata społecznego). Z tych też powodów rzeczywistość polityczna stanowi rację bytu dla wyobraźni politologicznej, a ukazane głębokie osadzenie tej szczególnej predyspozycji w realiach polityki i polityczności odróżnia ją zdecydowanie od fantazji, tym bardziej fantazji politologa.

Drugi trop eksplanacyjny z kolei, wynikający tym razem z myślenia naukowego, kieruje w stronę klasycznej pracy Charlesa Wrighta Millsa z 1959 roku Wyobraźnia socjologiczna (2007), sugerując, że interesująca nas kategoria jest implementacją koncepcji amerykańskiego badacza na gruncie politologicznym. Chociaż zastosowane $\mathrm{w}$ tym kontekście rozumowania per analogiam ogólnie wydaje się zasadne, pewne rozbieżności w samej koncepcji oraz w sposobie jej traktowania wymagają wyeksponowania. Po pierwsze, różnica między tymi kategoriami dotyczy - jak się wydaje - zakresu podmiotowego, który w koncepcji Millsowskiej obejmuje wszystkie podmioty kreujące - czy jedynie współobecne - w społeczeństwie, a w proponowanym wariancie wyobraźni politologicznej dotyczy przede wszystkim tych, którzy angażują się poznawczo w odkrywanie politycznych aspektów rzeczywistości. Co prawda amerykański badacz wprowadza pewien funkcjonalny i „genetyczny” podział, wyróżniając potoczną i naukową wyobraźnię socjologiczną, podkreśla jednak, że każdy powinien posiadać tę „najbardziej potrzebną cechę umysłu” (Mills, 2007, s. 63). Wyobraźnia politologiczna natomiast, nawiązująca do naukowego wariantu wyobraźni socjologicznej, stanowi predyspozycję bardziej poznawczą niż społeczną. Z tego powodu jej wykorzystania oczekuje się głównie od badacza, a dopiero w dalszej kolejności od pozostałych obywateli. Dodatkowo na gruncie socjologii koncepcja Millsa długo traktowana była jako pewna zamknięta koncepcja autorska (Keen, 1999), którą pozostali badacze przyjmowali bądź odrzucali en bloc. Tak, między innymi, czynili pomillsowscy twórcy perspektywy radykalnej w socjologii, traktując (niezależnie od wewnętrznego zróżnicowania tego nurtu) koncepcję prekursora jako gotowy projekt epistemologiczny, którego realizacja wymaga jedynie ściślejszego połączenia postępowania badawczego z praktyką społeczną (Mucha, 1986, s. 111). Na gruncie nauki o polityce taki kanoniczny stosunek do tejże propozycji nie znajduje uzasadnienia nie tylko dlatego, że bardziej efektywne (przy odmiennym umocowaniu przedmiotowym) okazuje się selektywne

Symptomatyczny w tym kontekście wydaje się fakt, że ta podstawowa dla perspektywy interpretacyjnej (i przypisywana przez długie lata jedynie temu nurtowi) teza, którą Anthony Giddens określił jako „zasadę podwójnej hermeneutyki”, została implementowana do głównego nurtu w naukach społecznych (Giddens, 2009). 
traktowanie Millsowskich treści, ale również dlatego, że pozwala ono na łączenie wybranych elementów, takich jak założenie o historycyzmie, dialektyczności czy współczynniku krytycznym, z wątkami epistemologicznymi wypracowanymi przez innych twórców bądź interpretatorów samego Millsa (Giddens, 1998, s. 23-28). Znaczenie pierwotnej koncepcji wyobraźni socjologicznej w kontekście konstruowania wyobraźni politologicznej polega więc na inspirowaniu bezpośrednio przez amerykańskiego klasyka, jak i pośrednio przez tych, których zainspirował sam Mills.

\section{0 problematycznym statusie wyobraźni politologicznej}

Lapidarnie rzecz ujmując, kluczem pozwalającym na ukazanie istoty i znaczenia wyobraźni politologicznej w badaniach rzeczywistości politycznej jest przedrostek „trans”. Istotą interesującej nas kategorii jest bowiem rudymentarna predyspozycja do przekraczania - szeroko pojętych - granic; zdolność do transmisji oraz transgresji niejednorodnych elementów i wymiarów rzeczywistości. Predyspozycja ta jednak nie ma wartości autotelicznej, lecz stanowi ogniwo pozwalające $\mathrm{z}$ jednej strony na łączenie rozmaitych składowych procesu badawczego, a z drugiej - na ich trwałe, jakościowe przekształcanie. Wyobraźnia politologiczna pojawia się więc "pomiędzy” - tam, gdzie potrzebne jest odkrywanie, łączenie czy przekształcanie.

Jakkolwiek wstępne ustalenia dotyczące tego, czym wyobraźnia politologiczna nie jest, ułatwiają niewątpliwie określenie jej specyfiki, kwestia statusu ontologicznego tej kategorii nadal sprawia badaczowi trudności. Wynikają one z próby odpowiedzi na pytanie, czy źródła predyspozycji określonej przez nas jako wyobraźnia politologiczna wypływają z psychobiologicznych zdolności do zmysłowej percepcji politycznych aspektów rzeczywistości, czy też z kognitywnych zdolności podmiotu. Dylemat powyższy sprowadza się więc do kwestii pewnych rozstrzygnięć epistemologicznego zakwalifikowania wyobraźni politologicznej w Carnapowskim porządku albo po stronie "odkrycia”, albo „uzasadnienia” (Krauz-Mozer, 2013, s. 45-56), w epistemologii zaś ostatnich lat: bądź po stronie eksternalizmu (podkreślającego znaczenie funkcjonowania podmiotu poznającego w rzeczywistości poznawanej), bądź internalizmu (głoszącego konieczność posiadania świadomości swojej kondycji epistemicznej [Ziemińska, 2002; por. też: Pierzchalski, 2017]).

Niezależnie od przyjętych przez badacza arbitralnych ustaleń dotyczących tychże kwestii pojawienie się owych dylematów świadczy o silnym, trwałym związku wyobraźni z dwoma odmiennymi wymiarami rzeczywistości: z porządkiem realnym oraz porządkiem poznania. W interesującej nas odmianie wyob- 
raźni politologicznej sposobem pozwalającym na rozstrzygnięcie przedstawionych dylematów jest określnik przymiotnikowy „politologiczny”, który nie tyle wskazuje na zakres podmiotowy dysponentów tej szczególnej predyspozycji (wszak nietrudno znaleźć przykłady nie-politologów posiadających imponującą wyobraźnię politologiczną [zob. Taleb, 2013; 2014), ile kieruje wektor eksplikacji tej kategorii bardziej w stronę nauki o polityce jako porządku poznania (ergo: uzasadniania), w którym poznający nie poprzestaje na samym postrzeganiu rzeczywistości (czy - jak chcą eksternaliści - na pozostawaniu „w trwałej i opartej na zaufaniu relacji ze światem" [Ziemińska, 2002, s. 115]), ale przede wszystkim nie ustaje w próbach jej wyjaśnienia i zrozumienia.

W tym kontekście wyobraźnia politologiczna ma charakter quasi-heurystyczny, z tą jednak istotną różnicą, że proponowane wskazania wektora nie redukują w pełni jej dualnej natury. Natura ta bowiem odzwierciedla jej trwałe zakorzenienie (za pomocą szczególnych „kotwic”) we wskazanych dwóch odmiennych porządkach, co związane jest $\mathrm{z}$ realizacją przez poznającego, dysponującego ową predyspozycją, dwóch imperatywów: wierności przedmiotowi badań politologicznych oraz nastawieniu na poszukiwanie prawdy. Chociaż imperatywy te nie brzmią dla badacza szczególnie nowatorsko, ich skuteczna realizacja we współczesnych warunkach już takiego nowatorskiego (wyobrażeniowego) elementu wymaga, ponieważ pozwala uniknąć błędów i pułapek wynikających z nieprzystawalności utrwalonych metod i perspektyw badawczy do zmieniającej się rzeczywistości społeczno-politycznej.

Szczególnym wyzwaniem dla współczesnego badacza polityki i polityczności okazuje się wspomniana wierność tak rozumianemu przedmiotowi, wymaga ona bowiem uwzględnienia jego historycznej zmienności. Postulat historycyzmu (wszak stanowiący jedną z głównych tez szkoły frankfurckiej [Horkheimer, 1983, s. 18]) nabiera wyjątkowego znaczenia i okazuje się szczególnym wyzwaniem, ponieważ $\mathrm{w}$ tym przypadku mamy do czynienia $\mathrm{z}$ całym zespołem wzajemnie rezonujących zmian.

Pierwszą, materialną płaszczyzną, na której dokonują się fundamentalne przemiany, jest $z$ jednej strony materia samej polityki, która coraz częściej funkcjonuje w oddzieleniu od materii państwa ${ }^{5}$ czy władzy $^{6}, \mathrm{z}$ drugiej strony - ma-

O skutkach dominacji perspektywy państwocentrycznej w naukach społecznych zob. m.in. Raport Komisji Gulbenkiana na rzecz Restrukturyzacji Nauk Społecznych „Otwórzmy nauki społeczne” (Wallerstein, 1999, s. 9-106).

6 „Władza, czyli zdolność działania, została oddzielona od polityki, czyli zdolności decydowania, co musi zostać zrobione i czemu należy przyznać priorytet. [...] Jedyne instytucje celowego działania zbiorowego pozostawione nam w spadku przez naszych rodziców i dziadków, ograniczone zakresowo do terytorium państw narodowych, wyraźnie się nie sprawdzają w obliczu globalnego zakresu naszych problemów, ich źródeł i konsekwencji” (Bauman, 2014, s. 112). 
teria polityczności, która po realnym (a nie tylko językowym) rozłączeniu z polityką ulega odrębnym modyfikacjom (Blok, 2013, s. 5-22). Implikuje to drugą, strukturalną płaszczyznę przemian, na której treści konstytuujące istotę zyskującej na znaczeniu polityczności nie tylko pojawiają się w różnych konfiguracjach, tworząc rozmaite syndromy (Karwat, 2009; 2010), ale dodatkowo przybierają odmienne formy (Karwat, 1996, s. 109-111). Współczesny badacz rzeczywistości politycznej mierzy się więc $\mathrm{z}$ wyzwaniami, od których wolni byli nawet sami twórcy teorii krytycznej ${ }^{7}$; chcąc podążać za polityką i politycznością, musi on w pierwszej kolejności przekroczyć granice instytucji (nie tracąc wszakże z horyzontu - żeby rzecz dodatkowo skomplikować - tych struktur i relacji politycznych, które tam jeszcze pozostały [Klementewicz, 2013]), a następnie wypatrywać przejawów uzgadniania potrzeb i interesów grupowych oraz ogólnospołecznych, występujących w różnych formach i konfiguracjach. Chociaż realizacja tego imperatywu wydaje się przedsięwzięciem z pogranicza naukowej ekwilibrystyki, stawką w tym przypadku jest prawda o rzeczywistości.

Realizacja imperatywu pierwszego stanowi zatem warunek sine qua non wypełnienia drugiego postulatu, ale i $\mathrm{w}$ tym przypadku posługiwanie się predyspozycją, którą określiliśmy jako wyobraźnię politologiczną, nie jest gwarantem poznania prawidłowości świata społeczno-politycznego, lecz raczej potencjałem stwarzającym dogodniejsze warunki do poszukiwania prawdy. Te korzystniejsze możliwości poznawcze powiązane są z transgeniczną naturą wyobraźni politologicznej, która w tym kontekście zostaje wyeksponowana w szczególny sposób - poprzez poszerzanie przestrzeni do zadawania pytań. W pierwszej kolejności praca wyobraźni (którą dalej określimy jako wyobraźnię „działającą wszerz") polega na konstruowaniu mostu pomiędzy potoczną (zdroworozsądkową) wiedzą o świecie społecznym, jaką kieruje się w swoich działaniach jednostka, a dotychczasową wiedzą naukową. Włączenie (na etapie protobadawczym) doxa w obszar poznawania polityczności (na Sennettowskich zasadach [Sennett, 2011]) pozwala nie tylko zrozumieć indywidualne doświadczenie podmiotu, ale przede wszystkim dostrzec i uwzględniać dialektyczną naturę rzeczywistości społecznej. Azymut poznania obejmuje więc również odkrywanie tego, co zakryte, niewidoczne, amorficzne, ponieważ - szczególnie w nauce o polityce - elementy te mogą stanowić nie tyle dopełnienie, ile sedno prawdy o rzeczywistości. Ponadto tak pojmowana wyobraźnia pozwala na łączenie (ergo: stosowanie) wiedzy o polityce i polityczności (teorii i metod) wypraco-

„Teoria krytyczna w swojej wczesnej fazie «burzy i naporu» nie uwzględniała możliwości takiego zerwania: było ono wówczas prawie niewyobrażalne (jego pojawiające się gdzieniegdzie oznaki można było odrzucić jako anomalie, tymczasowe zakłócenia, które wkrótce zostaną usunięte). Władza i polityka stanowiły dwa konieczne i wystarczające warunki skutecznego działania, a na obie monopol miało państwo" (Bauman, 2014, s. 152). 
wywanych na gruncie rozmaitych dyscyplin zgodnie z zasadą, że „miernikiem dojrzałości dyscyplinarnej jest nie tyle «zapał pogranicznika», cechujący niektórych jej reprezentantów, [ile] raczej świadomość dostępnych, acz rozsianych narzędzi odpowiadających wieloaspektowym fenomenom" (Ozimek, 2017, s. 168). Praca wyobraźni na rzecz prawdy polega zatem na mnożeniu pytań, a nie odpowiedzi, co stanowi skuteczną szczepionkę chroniącą badacza przed trywializacją i banałem ${ }^{8}$.

Podkreślmy jednak, że wyobraźnia politologiczna, jako szczególna predyspozycja badawcza, jest rodzajem potencjału umożliwiającego badaczowi szerszy i bardziej pogłębiony ogląd rzeczywistości politycznej. To jednak od samego badacza zależy, w jakim stopniu, do czego i jak tę umiejętność rozwinie i wykorzysta, w jakich okolicznościach poznawczych po nią sięgnie. W tym znaczeniu, pod względem epistemologicznym, jest ona genetycznie zakorzeniona $\mathrm{w}$ nurcie krytycznym, ale już niekoniecznie radykalnym. Związek z tym drugim nie ma charakteru zależności przyczynowej, lecz stanowi korelację, która - w politologicznej odmianie wyobraźni - wydaje się mniej oczywista niż w wypadku wyobraźni socjologicznej. Wyobraźnia politologiczna z kolei - pomimo jednoznacznych proweniencji krytycznych - nie wiąże badacza ściśle z żadnym konkretnym, dokładnie określonym (np. autorskim) projektem; bardziej go otwiera epistemicznie, niż dookreśla, czego skutkiem jest współobecność całego wachlarza postaw poznawczych wobec rzeczywistości politycznej lub jej wybranych elementów. Politolog, przywołując Janusza Muchę,

[...] by być krytyczny, często może ograniczyć się do odkrywania tego, co dominujący system ideologiczny czy polityczny usiłuje ukryć przed społeczeństwem (na przykład przez zakaz czy zniechęcanie do pewnego typu badań, przez cenzurę), czy też tego, co dzięki dominacji danego typu systemu ideologicznego jest trudne do dostrzeżenia. Wystarczy wówczas stosować po prostu „porządną”, choćby „pozytywistyczną", metodologię. Starannie wykonane badania [...] „głównego nurtu” przyczyniły się w wielkim stopniu do ujawnienia wielu nieprawidłowości społecznych i do zwiększenia zakresu wolności człowieka (Mucha, 1986, s. 14).

Te dwie bolączki często podnoszone są w dyskusjach nad kondycją współczesnych nauk społecznych. „Do tego dochodzi - dodaje Koźmiński - istotny, często powtarzany zarzut akademickiej głupoty, tzn. opowiadania w bardzo naukowej formie najróżniejszych dyrdymałek. [...] Ostatnio uczestniczyłem w bardzo uczonym seminarium na jednym z najsławniejszych uniwersytetów na świecie, na którym bardzo uczony i bardzo sławny człowiek, publikowany, przedstawił dorobek swojego życia, który mniej więcej można do tego sprowadzić, że rady nadzorcze dzielą się na pasywne i aktywne. Jeśli ktoś jest członkiem rady pasywnej, to następne zaproszenie otrzyma od rady pasywnej, a jak ktoś jest członkiem rady aktywnej, to następne zaproszenie też będzie od rady aktywnej. [...] a wszystko to było bardzo poważnie dyskutowane i przedstawiane" (Flis, 1999, s. 132-133). 
Jeśli więc, na przykład, współczesny politolog wyposażony w wyobraźnię politologiczną dostrzeże w swoich badaniach polityczne znaczenie nie tylko podmiotów dominujących w strukturze władczej, ale również (albo przede wszystkim) podmiotów podporządkowanych, to jego „odpowiedź” w formie postawy badawczej może być bardzo różna. Zależy ona bowiem zarówno od zakresu owej wyobraźni (jakie składowe: historycyzm, dialektyczność, współczynnik antropologiczny, krytyczny, radykalny, czy też kombinacje tych składowych, zawiera), jak i od jej intensywności, wyznaczającej stopień ingerencji w postawę (por. Ozimek, 2017, s. 172). Wyłaniają się więc wyraźnie dwa parametry organizujące pracę wyobraźni: oś pozioma, dotycząca wyobraźni „działającej wszerz”, oraz oś pionowa - skierowana do wyobraźni „działającej w głąb”. Ta pierwsza odnosi się do poznawczych składowych konstytuujących orientację badawczą, druga natomiast do składowych afektywnych, znajdujących odzwierciedlenie w postawie zarówno badawczej, jak i społeczno-politycznej (por. Napiórkowski, 2014, s. 106).

\section{Egzemplifikacja}

Egzemplifikacją tego zróżnicowania orientacji epistemicznych i postaw badawczych oraz wpływu na nie wymienionych parametrów wyobraźni politologicznej jest szeroki wachlarz perspektyw przyjmowanych przez współczesnych badaczy, podejmujących problematykę funkcjonowania kobiet w polityce. Wachlarz ten tworzą co najmniej trzy odmienne postawy epistemiczne, które określić można jako „politologię o kobietach”, „politologię feministyczną” oraz „feminizm politologiczny” (Kołodziejczak, 2011, s. 5-15). Chociaż ważną rolę w kształtowaniu każdej z nich odegrała predyspozycja, jaką określiliśmy mianem „wyobraźni politologicznej”, w pierwszym przypadku rola ta sprowadza się przede wszystkim do identyfikacji i adaptacji na grunt politologiczny nowego przedmiotu badań - kobiety w różnorodnych wymiarach jej politycznego funkcjonowania. Perspektywa ta - nazywana niekiedy (lekceważąco) „dodaniem kobiet" (Randall, 2006, s. 113-114) - przejawia się wpisaniem w kontekst rozważań politologicznych kwestii płci, co jednakże nie narusza w żaden sposób utrwalonych w nauce o polityce i realizowanych przy tej okazji neo- i postpozytywistycznych założeń epistemologiczno-metodologicznych. Wypracowana w takim modelu wiedza o polityczności kobiet spełnia wymogi naukowości zakładane w analityczno-empirycznym wzorcu badawczym ze wszystkimi tego konsekwencjami: z założeniem o obiektywizmie poznania naukowego, dystansem pomiędzy badaczem a przedmiotem/podmiotem poznania, oraz sztywną, metodologiczną procedurą empirycznej weryfikacji wypracowanych twierdzeń i teorii (Such, 1969, s. 243-297). Wyobraźnia przejawia się w tym wypadku roz- 
szerzeniem zakresu problematyki bez naruszania struktur metodologicznych nauki o polityce oraz bez angażowania badacza bezpośrednio w zmianę rzeczywistości politycznej.

W politologii feministycznej natomiast samo włączenie problematyki kobiet do nauki o polityce traktowane jest jako zabieg niewystarczający (a nawet niewłaściwy), nie stanowi on bowiem właściwej recepty na diagnozę problemu, jakiej zwolennicy tej perspektywy doszukują się w opresyjnych strukturach, dyskryminujących kobiety zarówno w rzeczywistości społeczno-politycznej, jak i w strukturze nauki. Rodzi to potrzebę rewizji i rekonstrukcji dotychczasowych politologicznych aksjomatów epistemologicznych pod takim kątem, aby uwzględniały postulaty epistemologii feministycznej z fundamentalnym założeniem o odmienności kobiecego doświadczenia poznawczego wraz z wszystkimi pochodnymi z niego wynikającymi (Pakszys, 1997, s. 39). Obecny wyraźnie $\mathrm{w}$ tej perspektywie element teoriokrytyczny narzuca oczywiście jako obowiązujący hermeneutyczny model poznania. W perspektywie tej wyobraźnia politologiczna silniej (niż w modelu wcześniejszym) odbija się na postawie badawczej, skłaniając do korekty nie tylko przedmiotu badań, ale i samych założeń poznawczych, nadal jednak bez pierwiastka radykalnego.

$\mathrm{W}$ przypadku feminizmu politologicznego samo poznanie (rozumienie) mechanizmów dyskryminacji dokonane za pomocą doskonalszych narzędzi badawczych nie jest jednak wartością autoteliczną, lecz stanowi niezbędny etap $\mathrm{w}$ procesie świadomego kreowania wolnej od wszelkiej opresji rzeczywistości politycznej. Nadrzędny postulat integralnego związku badań naukowych z aktywnością społeczną ${ }^{9}$ (projekt Action Research Marii Mies [zob. Pakszys, Sobczyńska, 1998, s. 131]) feministki badaczki realizują przede wszystkim poprzez taką kreację przestrzeni publicznej, aby sprzyjała ona ciągłości relacji społecznych oraz integralności społecznej egzystencji zarówno kobiet, jak i mężczyzn (Znaniecka Lopata, 1997, s. 535). W postawie tej bardzo wyraźnie odznaczają się wyróżnione wcześniej parametry wyobraźni politologicznej - nie tylko wszystkie jej składowe (poczynając od historycyzmu - przez dialektyczność i teoriokrytycyzm - na współczynniku antropologicznym i radykalnym kończąc), ale również intensywność jej oddziaływania.

Jürgen Habermas jako późny przedstawiciel teorii krytycznej sprowadziłby prawdopodobnie różnice pomiędzy przedstawionymi perspektywami do odmiennych interesów, w jakie uwikłane są trzy wyróżnione modele. W analityczno-

„Przy okazji zwróćmy uwagę, jak wybiórcza jest percepcja tego małżeństwa [...] nauki i praktyki w zależności od dyscypliny. [...] Cóż to byłby za profesor medycyny, ultramedyk, pożal się Boże, który nie był i nie umiałby być lekarzem, który w życiu nie operował. [...] Ale to samo kryterium przymierzone do politologa przez długie lata uchodziło za piętno. W jego przypadku to miałaby być okoliczność obciążająca" (Karwat, 2004, s. 14-15; zob. też: Młyńczyk, 2015, s. 85-100). 
-empirycznym wzorcu „politologii o kobietach” dostrzegłby wyraźnie tak zwany interes techniczny, w historyczno-hermeneutycznym modelu "politologii feministycznej” doszukałby się interesu praktycznego, natomiast w „feminizmie politologicznym", jako odmianie nauki krytycznej, podkreśliłby dominację interesu emancypacyjnego (Habermas, 1985, s. 157-169).

\section{Zakończenie}

Przedstawiona wyżej pozycja wyobraźni politologicznej - zarówno tej „działającej wszerz" (otwierającej horyzonty poznawcze na zmienność, złożoność i subiektywizm fenomenów politycznych oraz na historycyzm, kontekstowość i dialektyczność narzędzi ich poznawania), jak i tej „działającej w głąb” (skłaniającej badacza do poszukiwania własnego miejsca w świecie społecznym) - przypomina rolę aktora drugiego planu: organizującego przestrzeń, konstruującego relacje, budującego głębię psychologiczną, pomagającego rozwinąć akcję. Chociaż światła reflektorów i (ewentualne) uznanie ekspertów skierowane zostaną w ostateczności na teorię naukową, to wrażenie, jakie pozostawi ona na odbiorcach, zależy od jej współtowarzyszki - wyobraźni. Od wyobraźni zależy również, czy film, w którym razem wystąpią, będzie traktował o utraconych nadziejach, czy o spełnionych obietnicach.

\section{Literatura}

Bauman, Z. (2014). Rozmowy o socjologii. Zygmunt Bauman $w$ rozmowie $z$ Michaelem-Hviidem Jacobsenem i Keithem Testerem, przeł. P. Tomanek. Warszawa: Wydawnictwo Naukowe PWN.

Blok, Z. (2013). „Spheres and mechanisms generating political phenomena and processes". Polish Political Science Quarterly, 3.

Flis, A. (red.) (1999). Wyzwania wobec nauk społecznych u progu XXI wieku. Kraków: Universitas.

Giddens, A. (1998). Socjologia. Zwięzłe, lecz krytyczne wprowadzenie, przeł. J. Gilewicz. Poznań: Zysk i S-ka.

Giddens, A. (2009). Nowe zasady metody socjologicznej. Pozytywna krytyka socjologii interpretatywnych, przeł. G. Woroniecka, Kraków: Nomos.

Habermas, J. (1985). „Interesy konstytuujące poznanie”. Colloquia Communia, 2.

Hill, M. (2015). „The economic imagination”. Finance and Society, 1.

Horkheimer, M. (1983). „Teoria tradycyjna a teoria krytyczna”, przeł. J. Łoziński. Colloquia Communia, 2. 
Karwat, M. (1996). „Cecha polityczności i dziedzina teorii polityki”. W: R. Skarzyński (red.). Carl Schmitt i współczesna myśl polityczna. Warszawa: Dom Wydawniczy Elipsa.

Karwat, M. (2004). „Metodologiczne przewartościowania politologów”. Studia Nauk Politycznych, 1.

Karwat, M. (2009). „Syndromatyczny charakter przedmiotu nauki o polityce”. W: K.A. Wojtaszczyk, A. Mirska (red.). Demokratyczna Polska w globalizujacym się świecie. Warszawa: Wydawnictwa Akademickie i Profesjonalne.

Karwat, M. (2010). „Polityczność i upolitycznienie. Metodologiczne ramy analizy”. Studia Politologiczne, 1.

Karwat, M. (2012). O karykaturze polityki. Warszawa: Muza.

Keen, M. (1999). Stalking the Sociological Imagination. Westport-London: Greenwood Press.

Klementewicz, T. (2013). Geopolityka trwałego rozwoju. Ewolucja cywilizacji i państwa w trakcie dziejotwórczych kryzysów. Warszawa: Dom Wydawniczy Elipsa.

Kołodziejczak, M. (2011). „Politologia wobec feminizmu a feminizm wobec politologii”. Przegląd Politologiczny, 2.

Koźmiński, A.K. (2016). Wyobraźnia ekonomiczna. Warszawa: Poltext.

Krauz-Mozer, B. (2013). „Metodologia jako forma samowiedzy badawczej”. W: Ł. Młyńczyk, B. Nitschke (red.). Aspekty metodologiczne oraz teoretyczne w subdyscyplinach politologii. Toruń: Wydawnictwo Adam Marszałek.

LaCapra, D. (2009). Historia w okresie przejściowym. Doświadczenie, tożsamość, teoria krytyczna, przeł. K. Bojarska. Kraków: Universitas.

Mały słownik języka polskiego (1969). S. Skorupka, H. Auderska, Z. Łempicka (red.). Warszawa: PWN.

Mencwel, A. (2006). Wyobraźnia antropologiczna. Próby i studia. Warszawa: Wydawnictwa Uniwersytetu Warszawskiego.

Mills, C.W. (2007). Wyobraźnia socjologiczna, przeł. M. Bucholc. Warszawa: Wydawnictwo Naukowe PWN.

Młyńczyk, Ł. (2015). „Analiza u źródeł poznania teorii polityki i metodologii badań politologicznych w Polsce. Czy można i należy odseparować naukę od ideologii?”. Annales Universitatis Mariae Curie-Skłodowska, 2.

Mucha, J. (1986). Socjologia jako krytyka społeczna. Orientacja radykalna i krytyczna we współczesnej socjologii zachodniej. Warszawa: PWN.

Napiórkowski, M. (2014). Władza wyobraźni. Kto wymyśla, co zdarzyło się wczoraj. Warszawa: Wydawnictwa Uniwersytetu Warszawskiego.

Nęcka, E., Orzechowski, J., Słabosz, A., Szymura, B. (2005). Trening twórczości. Gdańsk: Gdańskie Wydawnictwo Psychologiczne.

Ozimek, M. (2016). „Czy politologia zaangażowana jest możliwa? Politolog(ia) jako zawód i obietnica”. W: B. Krzysztan, W. Ufel, M. Zieliński (red.). Polityka/polityczność. Granice dyskursu. Wrocław: Oficyna Wydawnicza Atut. 
Ozimek, M. (2017). „Wyobraźnia teoriopolityczna. Kilka uwag na marginesie książki «Rebelia i reakcja. Rewolucja 1905 roku i plebejskie doświadczenie polityczne» Wiktora Marca”. Society Register, 1.

Pakszys, E. (1997). „Feminizm w poszukiwaniu współczesnej tożsamości kobiet. Przykład filozofii poznania”. W: Z. Gorczyńska, S. Kruszyńska, I. Zakidalska (red.). Płeć. Kobieta. Feminizm, Gdańsk: Wydawnictwo Uniwersytetu Gdańskiego.

Pakszys, E., Sobczyńska, D. (1998). Kobiety w poznaniu naukowym wczoraj i dziś. Poznań: Wydawnictwo Naukowe UAM.

Pierzchalski, F. (2017). „Wyobraźnia twórcza - o źródłach teoretyzowania w nauce o polityce". Teoria Polityki, 1.

Pracontal, M. de (1983). „Kladystyka - nowa metoda klasyfikacji zwierząt”. Problemy, 10.

Randall, V. (2006). „Feminizm”. W: D. Marsh, G. Stoker (red.). Teorie i metody w naukach politycznych, przeł. J. Tegnerowicz. Kraków: Wydawnictwo Uniwersytetu Jagiellońskiego.

Sennett, R. (2011). „Humanism”. The Hedgehog Review, 2.

Such, J. (1969). Wstęp do metodologii ogólnej nauk. Poznań: Uniwersytet im. Adama Mickiewicza.

Taleb, N. (2013). Antykruchość. O rzeczach, którym służą wstrząsy, przeł. O. Siara. Warszawa: Kurhaus Publishing.

Taleb, N.( 2014). Czarny łabędź. O skutkach nieprzewidywalnych zdarzeń, przeł. O. Siara, T. Kasprowicz. Warszawa: Kurhaus Publishing.

Wallerstein, I. (red.) (1999). „Otwórzmy nauki społeczne”. W: A. Flis (red.). Wyzwania wobec nauk społecznych u progu XXI wieku, przeł. B. Lessaer. Kraków: Universitas.

White, H.V. (2014). „Polityka czasów nowoczesnych a sfera wyobraźni historycznej”. W: H.V. White. Przeszłość praktyczna, przeł. J. Burzyński [i in.]. Kraków: Universitas.

Willis, P. (2005). Wyobraźnia etnograficzna, przeł. E. Klekot. Kraków: Wydawnictwo Uniwersytetu Jagiellońskiego.

Ziemińska, R. (2002). Internalizm i eksternalizm we współczesnej epistemologii. Szczecin: Wydawnictwo Uniwersytetu Szczecińskiego.

Znaniecka Lopata, H. (1997). „Przenikanie się publicznej i prywatnej sfery życia. Wyzwanie rzucone przez kobiety społeczeństwu amerykańskiemu”. W: S. Kozyr-Kowalski, A. Przestalski, J. Włodarek (red.). Krytyka rozumu socjologicznego. Praca zbiorowa wydana z okazji 100-lecia urodzin Tadeusza Szczurkiewicza. Poznań: Zysk i S-ka.

\section{Streszczenie}

W artykule przedstawiono koncepcję „wyobraźni politologicznej” jako specyficznej predyspozycji badawczej, pozwalającej badaczowi na szerszy i bardziej pogłębiony ogląd rzeczywistości politycznej. Wskazując na możliwe pułapki w myśleniu o tej kategorii (nieuzasadnione 
utożsamianie z „fantazją” lub bezpośrednia implementacja na grunt politologiczny koncepcji Charlesa Wrighta Millsa), autorka ukazuje dwoistą naturę tejże predyspozycji. Chociaż pozostaje ona $\mathrm{w}$ trwałym związku $\mathrm{z}$ dwoma odmiennymi wymiarami rzeczywistości: $\mathrm{z}$ porządkiem realnym oraz porządkiem poznania, jej podstawowy wektor oddziaływania skierowany jest w stronę poznawania, a nie kreowania realnej rzeczywistości. Ma więc ona charakter quasi-heurystyczny, jednak jej posiadanie nie ewokuje konkretnej postawy badawczej. Ta bowiem uzależniona jest zarówno od zakresu owej wyobraźni (jakie składowe zawiera: historycyzm, dialektyczność, współczynnik antropologiczny, krytyczny), jak i od jej intensywności (określającej gotowość do ingerencji badacza w świat społeczno-polityczny).

Słowa kluczowe: wyobraźnia politologiczna, wyobraźnia socjologiczna, poznanie w nauce o polityce 